\title{
Pengaruh Paparan Uap Rokok Elektrik Terhadap Gambaran Histopatologi Organ Pulmo Tikus Putih (Rattus norvegicus)
}

\section{The Effect of Electric Cigarette Exposure on The Histopathology of Pulmo in Albino Rats (Rattus norvegicus)}

\author{
Carolina Ardy ${ }^{1 *}$, Iwan Sahrial Hamid², Aditya Yudhana $^{3}$, Widjiati ${ }^{4}$, Muhammad \\ Thohawi Elziyad Purnama ${ }^{4}$, Faisal Fikni² \\ ${ }^{1}$ Pendidikan Dokter Hewan, ${ }^{2}$ Bagian Ilmu Kedokteran Dasar Veteriner, ${ }^{3}$ Bagian Parasitologi Veteriner, \\ ${ }^{4}$ Bagian Anatomi Veteriner, \\ Fakultas Kedokteran Hewan, Universitas Airlangga \\ *Corresponding author: carolina.ardy.mega-2015@fkh.unair.ac.id
}

\begin{abstract}
Abstrak
Studi ini bertujuan untuk mengidentifikasi pengaruh paparan uap rokok elektrik terhadap gambaran histopatologi organ pulmo. Tikus putih yang digunakan sebanyak 20 ekor yang terbagi menjadi 5 kelompok, kontrol (K) adalah yang tidak diberikan paparan uap rokok elektrik dan kelompok perlakuan yang diberikan paparan uap dengan dosis yang berbeda, kelompok Perlakuan I (0,3 mg/ml), P2 (3 mg/ml), P3 (12 mg/ml), P4 (36 mg/ml). Setelah 14 hari perlakuan, tikus putih dieuthanasia dan dinekropsi serta organ pulmo diawetkan untuk dilakukan pembuatan preparat histopatologi dengan menggunakan pewarnaan Hematoxilin-Eosin. Hasil menunjukkan terdapat kerusakan pada gambaran histopatologi pulmo yang diamati pada perbesaran 400x. analisis data menggunakan Kruskal-Wallis dan dilanjutkan dengan uji Mann Whitney menunjukkan perbedaan yang signifikan $(\mathrm{p}<0.05)$. Rata-rata kerusakan organ pulmo tikus putih adalah kontrol $(\mathrm{K})=3.00 ;(\mathrm{P} 1)=6.00$; $(\mathrm{P} 2)=12.00$; $(\mathrm{P} 3)=13.00$ dan $(\mathrm{P} 4)=18.50$ dan dosis minimal dari nikotin adalah $3 \mathrm{mg} / \mathrm{ml}$. Kesimpulan, paparan uap rokok elektrik dapat menyebabkan kerusakan yang signifikan pada organ pulmo tikus putih.
\end{abstract}

Kata kunci: histopatologi, pulmo, Rattus norvegicus, rokok elektrik

\section{Abstract}

This study aimed to identify the pulmo histopathology figure of albino rats exposured to an e-cigarette. A total of 20 rats divided in 5 groups, control group (K) were not exposed by e-cigarette and treatment group were exposed by e-cigarette in different doses, P1 (0,3mg/ml), P2 (3mg/ml), P3 (12 mg/ml), P4 (36 mg/ml) respectively. After 14 days of treatment, rats were euthanasia and necropsy method was performed to identify macroscopy change, also the pulmo organs were dissected and preserved for histopathological study using Hematoxilin-Eosin staining. The results showed that damage of pulmo was defected within histopathology examination using 400x magnification. Moreover, the data were analyzed using Kruskal-Wallis test and continued by Mann Whitney Test which show a significant difference $(\mathrm{p}<0.05)$. Average result from pulmo organs of Rats were Control $(\mathrm{K})=3.00 ;(\mathrm{P} 1)=6.00 ;(\mathrm{P} 2)=12.00 ;(\mathrm{P} 3)=13.00$ and $(\mathrm{P} 4)=18.50$ and nicotine dose of minimum was $3 \mathrm{mg} / \mathrm{ml}$. In conclusion, the exposure of an e-cigarette have significant damage effect of pulmo organs in rats.

Key words: e-cigarettes, histophatology, pulmo, Rattus norvegicus

Received: 13 Mei 2019

Revised: 18 Juni 2019

Accepted: 29 Juli 2019

\section{PENDAHULUAN}

Organ pulmo merupakan salah satu organ yang sering mengalami kelainan patologis, karena organ ini memiliki fungsi sebagai tempat pertukaran $\mathrm{O}_{2}$ dan $\mathrm{CO}_{2}$ yang mana akan berkontak langsung dengan udara luar. Sel pada struktur anatomis pulmo yang berperan dalam pertukuran $\mathrm{O}_{2}$ dan $\mathrm{CO}_{2}$ adalah alveoli, udara akan berdifusi melalui dinding alveoli atau septa interalveolaris. Epler (2000), menyatakan bahwa berbagai faktor yang berpengaruh dalam timbulnya penyakit saluran pernafasan terdiri atas faktor debu yang berupa ukuran partikel, 
konsentrasi, dan faktor individual meliputi mekanisme pertahanan yang dilakukan oleh organ pulmo.

Rokok elektrik merupakan perangkat dengan baterai yang diciptakan untuk menghantarkan nikotin dalam bentuk uap sehingga dapat masuk ke dalam sistem pernafasan. Rokok elektrik dirancang untuk menghantarkan bahan kimia dan nikotin yang ditambahkan ke dalam perangkat melalui sistem pernafasan sehingga akan menghasilkan uap yang dapat dihirup (Etter et al., 2013). World Health Organization mengistilahkan perangkat ini sebagai Electronic Nicotine Delivery System. Kandungan dalam rokok elektrik disebut sebagai e-liquid yang terdiri dari propylene glycol (PG), vegetable glycerine (VG), perasa (flavors), dan nikotin (Hajek et al., 2014).

Menurut Callahan-Lyon (2014), larutan yang termasuk nikotin dan bahan kimia lain dalam rokok elektrik dapat menyebabkan iritasi pada organ pulmo. Paparan karena uap rokok elektrik menimbulkan peradangan pada organ pulmo, serta penurunan fungsi normal organ pulmo. Pisinger (2014), menyebutkan bahwa paparan rokok elektrik dapat mempengaruhi peningkatan respon peradangan dari neutrofil dan makrofag.

Peradangan merupakan gejala umum yang menjadi ciri pathogenesis yang disebabkan karena terhirupnya suatu partikel yang masuk ke dalam sistem pernafasan. Perubahan histologi yang terjadi pada organ pulmo jika terkena paparan nikotin dalam rokok elektrik akan meningkatkan infiltrasi sel radang dalam organ pulmo sehingga beresiko terhadap kerusakan jaringan.

Uap rokok elektrik merupakan patikel yang dapat mempengaruhi metabolisme makrofag dalam alveoli, dengan cara mengaktifkan makrofag untuk melepaskan sel yang menyebabkan dilepaskannya faktor kemotatik neutrofil. Faktor tersebut akan merangsang neutrofil untuk melepaskan protease yang akan merusak jaringan ikat parenkim pulmo, sehingga akan menyebabkan kerusakan pada dinding alveoli (Dietrich et al., 2003). Partikel yang tertimbun secara terus menerus, akan mempengaruhi peningkatan jumlah sel radang sehingga menyebabkan penebalan pada dinding alveoli (Lenzatti et al., 2011).

Nikotin dalam rokok elektrik juga akan bekerja menghambat proses asetilkolinerase pada organ pulmo sehingga menyebabkan terjadinya akumulasi asetilkolin yang merangsang bronkus untuk berkontriksi dan menyebabkan destruksi pada dinding saluran pernafasan. Destruksi dinding saluran pernafasan akan meningkatkan cairan sitoplasma pada insterstitial atau seluruh tubuh sehingga memicu terjadi oedema pada lumen alveoli. Oedema yang terjadi pada alveoli menyebabkan pelebaran pada lumen alveoli (Lenzatti et al., 2011).

Berdasarkan potensi pulmo sebagai organ yang rentan mengalami kerusakan akibat paparan uap rokok elektrik, maka peneliti ingin mengetahui pengaruh paparan uap rokok elektrik dengan berbagai konsentrasi nikotin terhadap gambaran histopatologi organ pulmo tikus putih (Rattus norvegicus).

\section{METODE PENELITIAN}

Penelitian dilakukan terhadap 20 ekor tikus puth (Rattus norvegicus) galur Sprague dawley. Tikus putih dibagi ke dalam 5 kelompok yaitu kelompok control (K), kelompok yang tidak diberikan perlakuan tetapi diberikan makan dan minum, kelompok P1 diberikan paparan uap rokok elektrik dengan $e$-liquid yang mengandung nikotin $0,3 \mathrm{mg} / \mathrm{ml}$, P2 (3 mg/ml), P3 (12 mg/ml) dan P4 $(36 \mathrm{mg} / \mathrm{ml})$. Perlakuan diberikan selama 14 hari, setelah hari ke-15 tikus puth di Euthanasia. Kemudian di bedah dan dipisahkan organ pulmonya.

Organ pulmo kemudian di fiksasi dalam larutan Buffered Neutral Formalin 10\% untuk dilakukan pembuatan preparat histopatologi dengan pewarnaan Hematoxyline-Eosin (HE) dan dilakukan pengamatan histopatologi pada perbesaran 400x menggunakan Mikroskop Trinokuler. Dilakukan dengan mengambil gambaran histopatologi pada 5 lapang pandang tiap organ pulmo tikus putih, kemudian dilakukan pengamatan dengan melakukan skoring tingkat kerusakan organ pulmo. 
Skoring tingkat kerusakan organ pulmo menurut (Roselyn et al., 2011) diambil parameter berupa hemorraghi, Oedema, Infiltrasi sel radang, penebalan septa interalveoli, pelebaran lumen alveoli dan granuloma dan perhitungan skoring dilakukan menurut (Hansel dan Barnes, 2004; Lenzatti, 2011), yaitu: (Skor 0) tidak terdapat kerusakan pada organ pulmo; (Skor 1) terdapat kerusakan organ pulmo kurang dari sepertiga lapang pandang; (Skor 2) terdapat kerusakan organ pulmo pada sepertiga hingga duapertiga lapang pandang; (Skor 3) terdapat kerusakan organ pulmo lebih dari duapertiga lapang pandang.

Nilai skor pada keenam parameter kemudian dilakukan perhitungan dengan rumus, yaitu sebagai berikut:

$\%$ nilai kerusakan $=\frac{\bar{x}}{18} \times 100 \%$

Keterangan: $\bar{x}=$ rata-rata keenam parameter skoring; $18=$ skor maksimum $(3 \times 6$ parameter $=18$ ).

Data kemudian dianalisis dengan uji Kruskal-Wallis lalu dilanjutkan Uji MannWhitney U jika terdapat perbedaan signifikan $(\mathrm{p}<0.05)$.

\section{HASIL DAN PEMB AHASAN}

Berdasarkan hasil pengamatan secara mikroskopis diperoleh adanya perbedaan antara masing-masing kelompok perlakuan. Kelompok kontrol pada tabel 1 dan 2. menunjukkan kerusakan organ pulmo dengan hasil skoring yaitu $15 \%$ dan secara pengamatan histopatologi didapatkan adanya sedikit hemorraghi dan oedema namun, tidak ditemukkan kerusakan berupa penebalan septa interalveolar, infiltrasi sel radang maupun pelebaran lumen alveoli dan granuloma.

Kelompok Perlakuan 1 (P1) terdapat kerusakan berupa hemorraghi, oedema, dan sedikit infiltrasi sel radang yang menyebabkan penebalan pada septa intealveolar namun, tidak didapatkan adanya kerusakan berupa granuloma. Hasil pengamatan secara mikroskopis pada kelompok P2 dan P3 juga tidak menunjukkan perbedaan yang signifikan tetapi termasuk dalam kerusakan sedang. Kelompok P4 merupakan kelompok yang menunjukkan hasil yang paling signifikan dibandingkan kelompok kontrol dan kelompok perlakuan P1,P2, dan P3 atau termasuk dalam kelompok dengan kategori kerusakan berat berdasarkan klasifikasi skoring (Tabel 1).

Berdasarkan hasil analisis statistik yang menyebutkan bahwa pada kelompok K dan P1 tidak terjadi perubahan histopatologi yang signifikan atau dalam kategori kerusakan ringan. Hasil pengamatan secara mikroskopis pada kelompok P2 dan P3 juga tidak menunjukkan perbedaan yang signifikan tetapi termasuk dalam kategori kerusakan sedang. Kelompok P4 merupakan kelompok yang menunjukkan hasil yang paling signifikan dibandingkan kelompok kontrol dan kelompok perlakuan P1, P2, dan P3 atau termasuk dalam kelompok dengan kategori kerusakan berat berdasarkan klasifikasi skoring, dimana pada pengamatan preparat histopatologi ditemukan perubahan yang sangat jelas dan berbeda nyata secara statistik yaitu rata-rata kerusakan 18.50 (Tabel 2).

Aerosol atau partikel yang masuk ke alveoli akan diabsorbsi ke dalam sistem peredaran darah atau dibersihkan oleh sel- sel imun yaitu makrofag (WHO, 2006). Makrofag pada organ pulmo disebut sebagai makrofag alveolar. Partikel yang terinhalasi, akan direspon oleh respon imun yang bersifat non-spesifik berupa reaksi peradangan atau inflamasi. Timbulnya reaksi peradangan bertujuan untuk mengeliminasi dan memperbaiki jaringan yang rusak akibat antigen asing (Slauson dan Cooper, 2002). Beberapa penelitian membuktikan, bahwa paparan asap rokok dapat mempengaruhi jumlah aktivitas makrofag alveolar.

Berdasarkan hasil pengamatan histopatologi organ pulmo menunjukkan jumlah sel radang meningkat pada kelompok yang diberikan perlakuan paparan uap rokok elektrik dibandingkan kelompok yang tidak diberikan perlakuan atau kontrol (Gambar 1). Hal tersebut sejalan dengan penelitian yang dilakukan oleh Lopes dkk., (2013), yang menjelaskan bahwa tikus yang diberikan perlakuan berupa paparan asap rokok mengalami peningkatan jumlah makrofag alveolar yang signifikan dibandingkan dengan tikus yang tidak diberikan paparan asap 
Tabel 1. Hasil skoring tingkat kerusakan organ pulmo tikus puth

\begin{tabular}{ccc}
\hline Kelompok Pe rlakuan & Presentase Hasil Skoring Kategori \\
\hline Kontrol & $15 \%$ & Ringan \\
P1 $(0.3 \mathrm{mg} / \mathrm{ml})$ & $20.20 \%$ & Ringan \\
P2 $(3 \mathrm{mg} / \mathrm{ml})$ & $39.40 \%$ & Sedang \\
P3 $(12 \mathrm{mg} / \mathrm{ml})$ & $43.80 \%$ & Sedang \\
P4 $(36 \mathrm{mg} / \mathrm{ml})$ & $61.90 \%$ & Berat \\
\hline
\end{tabular}

Tabel 2. Hasil rata-rata $(\bar{x} \pm \mathrm{SD})$ kerusakan organ pulmo tikus putih

\begin{tabular}{|c|c|}
\hline \multicolumn{2}{|c|}{ Kelompok PerlakuanKe rus akan pulmo $\left(\mathrm{x}^{-} \pm \mathrm{SD}\right)$} \\
\hline Kontrol & $3.00^{\mathrm{a}} \pm 0.114$ \\
\hline $\mathrm{P} 1(0.3 \mathrm{mg} / \mathrm{ml})$ & $6.00^{\mathrm{a}} \pm 0.183$ \\
\hline P2 (3 mg/ml) & $12.00^{\mathrm{b}} \pm 0.321$ \\
\hline P3 (12 mg/ml) & $13.00^{b} \pm 0.185$ \\
\hline P4 (36 mg/ml) & $18.50^{c} \pm 0.196$ \\
\hline
\end{tabular}

Superskrip berbeda menunjukkan perbedaan signifikan $(\mathrm{p}<0.05)$
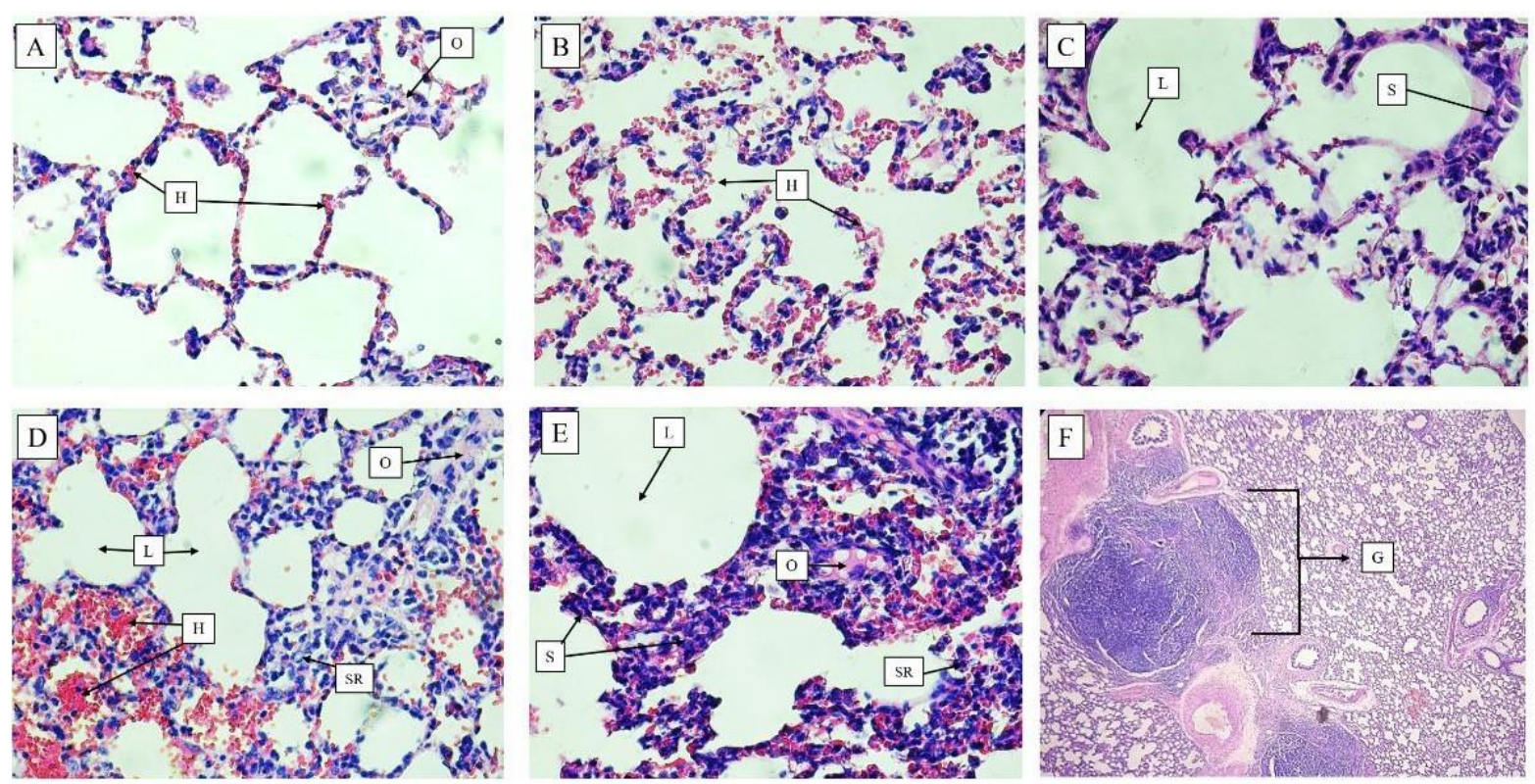

Gambar 1. Gambaran histopat organ pulmo tikus putih pada semua perlakuan

Keterangan: A=Kelompok normal $(\mathrm{K}) ; \mathrm{B}=\mathrm{P} 1 ; \mathrm{C}=\mathrm{P} 2 ; \mathrm{D}=\mathrm{P} 3 ; \mathrm{E}=\mathrm{P} 4 ; \mathrm{H}=$ Hemorraghi; $\mathrm{O}=$ Oedema; $\mathrm{Sr}=$ Infiltrasi Sel Radang; $\mathrm{S}=$ Penebalan Septa Interalveoli; L= Pelebaran Lumen; G= Granuloma

rokok. Pada hasil histopatologi kelompok normal atau kontrol menunjukkan hubungan antar alveoli rapat karena kelompok kontrol tidak mengalami perlakuan, namun pada salah satu pengulangan yang lain, ditemukkan adanya kelainan organ pulmo. Perubahan kerusakan organ pulmo tersebut terjadi karena adanya pengaruh dari luar yang tidak dapat dikendalikan seperti genetik, kondisi kesehatan individu tikus ataupun psikologi tikus.
Peradangan merupakan respon vaskuler yang ditandai oleh vasodilatasi, dimana terdapat peningkatan volume darah ke dalam mikrosirkulasi lokal sehingga menyebabkan akumulasi eritrosit pada jaringan interstitial meningkat yang disebut hemorraghi. Mekanisme terjadinya kerusakan organ pulmo akibat paparan asap rokok dimulai ketika radikal bebas masuk ke dalam sistem pernafasan, sehingga tubuh akan merespon keluarnya mediator inflamasi. Paparan 
rokok elektrik akan menyebabkan kerusakan yang disebabkan karena keluarnya mediator inflamasi berupa kemokin Interleukin-8 (IL-8), dimana IL-8 tersebut akan mengaktivasi neutrofil (Hamid dkk., 2018). Kerusakan organ pulmo yang ditunjukkan dengan adanya aktivitas infiltrasi sel radang yang ditandai dengan banyaknya makrofag alveolar berupa akumulasi neutrofil pada matriks ekstraseluler septa interalveoli.

Neutrofil dan makrofag memegang peran penting dalam sistem pertahanan tubuh, sel imun tersebut dapat memproduksi dalam jumlah banyak jika partikel yang masuk bersifat sangat toksik (Purnama dan Samik, 2014). Produksi neutrofil dan makrofag yang meningkat akan menyebabkan penebalan pada septa interalveolaris. Hasil pengamatan histopatologi organ pulmo pada semua kelompok perlakuan menunjukkan adanya peningkatan ketebalan septa interalveoli. Hal ini sejalan dengan pernyataan Junqueira dan Carneiro (2009), yang menyebutkan bahwa peningkatan makrofag alveolar akan menyebabkan destruksi septa berupa penebalan septa interalveoli.

Kerusakan lain yang ditemukan pada histopatologi organ pulmo tikus puth yang diberikan paparan uap rokok elektrik adalah pelebaran lumen alveoli. Makrofag alveolar yang teraktivasi akan mensekresikan senyawa sitokin proinflamasi seperti Tumor Necrosis Factor- $\alpha$ (TNF- $\alpha$ ) dan faktor kemotatik Interleukin-8 (IL8). Aktivitas ini mengakibatkan terjadinya fibrosis pada jaringan pulmo. Nikotin pada rokok elektrik dapat memicu pelepasan fibronectin yang menyebabkan fibrosis pada parenkim organ pulmo yang dapat merusak jaringan elastin pada pulmo sehingga menyebabkan pelebaran lumen alveoli.

Nikotin merupakan zat yang menyerupai molekul asetilkolin yaitu salah satu neurotransmitter penting yang berada pada otak (USDHHS, 2010). Asetilkolin pada sistem pernafasan berperan penting dalam pengaturan tonus bronkomotor yaitu reflek parasimpatis yang dapat menyebabkan kontriksi pada bronkus. Nikotin dalam rokok elektrik akan bekerja menghambat proses asetilkolinerase pada organ pulmo sehingga menyebabkan terjadinya akumulasi asetilkolin yang merangsang bronkus untuk berkontriksi dan menyebabkan destruksi pada dinding alveoli. Proses tersebut akan menyebabkan peningkatan aktivasi dari Granuloma atau Bronchus Associated Lymphoid Tissue (BALT).

BALT terdiri dari agregat limfosit yang mengandung limfosit $\mathrm{B}$ dan limosit $\mathrm{T}$ (Renne et al., 2009). Nikotin pada rokok elektrik yang terinhalasi akan merespon tubuh untuk meningkatkan sistem pertahanan berupa kumpulan sel limfosit. Berdasarkan hasil pengamatan, pada kelompok perlakuan yang diberikan paparan uap rokok elektrik dengan penambahan nikotin diperoleh adanya peningkatan ukuran granuloma, sehingga dapat diketahui bahwa nikotin yang bertingkat akan meningkatkan proliferasi limfosit sebagai bentuk pertahanan lokal. Hal tersebut sejalan dengan Randall (2010), yang menyebutkan bahwa proses aktivasi BALT dapat terjadi ketika terdapat mikoorganisme atau benda asing yang masuk ke dalam saluran pernafasan akan memberikan stimuli sehingga limfosit dapat berprolierasi sebagai bentuk pertahanan lokal (Randall, 2010).

Berdasarkan hasil pengamatan, pada kelompok perlakuan yang diberikan paparan uap rokok elektrik dengan penambahan nikotin diperoleh adanya peningkatan ukuran granuloma, sehingga dapat diketahui bahwa nikotin yang bertingkat akan meningkatkan proliferasi limfosit sebagai bentuk pertahanan lokal. Hasil penelitian menujukkan bahwa perlakuan dengan paparan nikotin minimal yaitu $3 \mathrm{mg} / \mathrm{ml}$ didapatkan granuloma dengan ukuran kecil, hal ini terjadi karena terdapat mobilisasi sel-sel pertahanan tubuh menuju daerah yang mengalami peradangan, sedangkan pada paparan dengan nikotin $12 \mathrm{mg} / \mathrm{ml}$ dan $36 \mathrm{mg} / \mathrm{ml}$, BALT menjadi semakin membersar seiring dengan tingkatan dosis nikotin yang diberikan.

\section{KESIMPULAN}

Terdapat kerusakan pada organ pulmo tikus putih galur Sprague dawley yang telah diberikan 
paparan uap rokok elektrik terhadap gambaran histopatologi organ pulmo. Dosis nikotin minimal pada rokok elektrik yang dapat menyebabkan kerusakan pada organ pulmo adalah $3 \mathrm{mg} / \mathrm{ml}$.

\section{UCAPAN TERIMA KASIH}

Ucapan terima kasih ditujukan kepada Kepala Bagian Labolatorium Fakultas Kedokteran Hewan PSDKU Universitas Airlangga di Banyuwangi atas izin yang telah diberikan untuk dilakukan penelitian ini.

\section{DAFTAR PUSTAKA}

Dietrich, M., Gladys, B., Edward, P.N., Mark, H., Maret, G.T., Caroll, E.C., Lester, P. 2003. Smoking And Exposure To Environmental Tobacco Smoke Decrease Some Plasma Antioxidants And Increase Tocopherol In Vivo After Adjustment For Dietary Antioxidants Intakes. Am. J. Clin. Nutr., 77, 160-6.

Etter, J.F., Zather, E., Svensson, S. 2013. Analysis of refill liquids for electronic cigarettes. Addiction, 108(9), 1671-1679.

Epler. 2000. Environmental and Occupational Lung Disease in: Clinical Overview of Occupational Disease, J. Occup. Environ. Med., 76, 324-5.

Hajek, P., Goniewicz, M.L., McRobbie, H. 2014. Nicotine content of electronic cigarettes, its release in vapour and its consistency across batches regulatory implications. Addiction, 109(3), 500-507.

Hansel, T.T., Barnes, P.J. 2004. An Atlas of Chronic Obstructive Pulmonary Disease. London: Parthenon Publishing Group. pp 22-36.

Chen, I.L., Husten, C.G. 2014. Introduction to tobacco control supplement. Tobacco Control, 23(5), 25.
Hamid, I.S., Aksono, E.B., Sukmanadi, M., Purnama, M.T.E. 2018. Antiangiogenesis activity test of tin leaf (Ficus carica L.) on the number of blood vessels and VEGF expression of chorioallantoic membrane of embryonated chicken eggs. Eur. J. Oncol. Pharm., 1(4), e00007.

Jungquiera, L.C., Carneiro, J. 2007. Histologi Dasar Teks dan Atlas 10th Ed. Jakarta: EGC. pp 335-54.

Lenzatti, M., Alan, L., Thiago, S., Ferreira, R.S.M., Angela, R., Luis, C.P., Samuel, S.V. 2011. Mate Tea Ameliorates Emphysema In Cigarette Smoke-Exposed Mice. Experimental Lung Research. pp 246-257.

Lopes, A.G., Thiago, S.F., Renata, T.N., Manuella, L., Karla, M.P.P., Ari, M.S., Ricardo, M.B., Antonio, J.R.S., Samuel, S.V., Luis, C.P. 2013. Antioxidant Action Of Propolis On Mouse Lungs Exposed To Short-term Cigarette Smoke, Bioorg. Med. Chem., 21(24), 7570 - 7577.

Pisinger, C., Dossing, M. 2014. A systematic review of health effects of electronic cigarettes. Prev. Med., 69, 248-260.

Purnama, M.T.E., Samik, A. 2014. Potential mycotoxin binders on histopathology of the mammary gland experiencing neoplasia in pregnant mice (Mus musculus) with exposed zearalenone. Vet. Med, 7(1), 73-80.

Randall, T.D. 2010. Bronchus-associated lymphoid tissue (BALT) structure and function. Adv. Immunol, 107, 184-241.

Renne, R.A., Dungworth, D.L., Keenan, C.M., Morgan, K.T., Hahn, F.F., Schwartz, L.W. 2009. Proliferative and nonproliferative lesions of the rat and mouse respiratory tract. Toxicol. Pathol., 37(7), 


\section{S-73S.}

Roselyn, A., Pradita, W., Endang, L., Susanto, G, Nugroho, Sutyarso. 2016. Pengaruh pemberian taurin terhdapat gambaran histopatologi paru mencit (Mus musculus) yang diinduksi kasinogen benzo( $\alpha)$ Piran secara In Vitro. J. Nat. Indon., 17(1).

Slauson, Cooper, B.J. 2002. Mechanism of disease, textbook of comparative general pathology. Chapter 4: Inflammation and Repair o Tissue. 3rd ed. pp 141- 245.
U.S Department Of Health And Human Services. 2010. How Tobacco Smoke Cause Disease: The Biology and Behavioral Basis for Smoking Attributable Disease. Public Health Service: The Surgeon General. Rockville, MD.

WHO. 2006. Hazardous Chemical in Human and Environmantal Health (Widyastuti P. Trans). Jakarta:Penerbit Buku Kedokteran EGC. 